\title{
Light and electron microscopy characteristics of the muscle of patients with SURF1 gene mutations associated with Leigh disease
}

\author{
M Pronicki, ${ }^{1}$ E Matyja, ${ }^{2}$ D Piekutowska-Abramczuk, ${ }^{3}$ T Szymańska-Debińska, ${ }^{1}$ \\ A Karkucińska-Więckowska, ${ }^{1}$ E Karczmarewicz, ${ }^{4}$ W Grajkowska, ${ }^{1}$ T Kmieć, ${ }^{5}$ \\ E Popowska, ${ }^{3}$ J Sykut-Cegielska ${ }^{6}$
}

${ }^{1}$ Department of Pathology, The Children's Memorial Health Institute, Warsaw, Poland;

${ }^{2}$ Department of Metabolic Diseases, Endocrinology and Diabetology, The Children's Memorial Health Institute, Warsaw, Poland; ${ }^{3}$ Department of Medical Genetics, The Children's Memorial Health Institute, Warsaw, Poland; ${ }^{4}$ Department of Biochemistry and Experimental Medicine, The Children's Memorial Health Institute, Warsaw, Poland;

${ }^{5}$ Department of Neurology and Epileptology, The Children's Memorial Health Institute, Warsaw, Poland; ${ }^{6}$ Department of Experimental and Clinical Neuropathology, M.

Mossakowski Medical Research Centre, Polish Academy of Sciences, Warsaw, Poland

Correspondence to:

Associate Professor M Pronicki, Department of Pathology The Children's Memorial Health Institute, Aleja Dzieci Polskich 20, 04-730 Warsaw, Poland; mpronicki@poczta.onet.pl

Accepted 7 September 2007

Published Online First

1 October 2007

\section{ABSTRACT}

Aims: Leigh syndrome (LS) is characterised by almost identical brain changes despite considerable causal heterogeneity. SURF1 gene mutations are among the most frequent causes of LS. Although deficiency of cytochrome $c$ oxidase (COX) is a typical feature of the muscle in SURF1-deficient LS, other abnormalities have been rarely described. The aim of the present work is to assess the skeletal muscle morphology coexisting with SURF1 mutations from our own research and in the literature.

Methods: Muscle samples from 21 patients who fulfilled the criteria of LS and SURF1 mutations (14 homozygotes and 7 heterozygotes of c.841delCT) were examined by light and electron microscopy.

Results: Diffuse decreased activity or total deficit of COX was revealed histochemically in all examined muscles. No ragged red fibres (RRFs) were seen. Lipid accumulation and fibre size variability were found in 14 and 9 specimens, respectively. Ultrastructural assessment showed several mitochondrial abnormalities, lipid deposits, myofibrillar disorganisation and other minor changes. In five cases no ultrastructural changes were found. Apart from slight correlation between lipid accumulation shown by histochemical and ultrastructural techniques, no other correlations were revealed between parameters investigated, especially between severity of morphological changes and the patient's age at the biopsy.

Conclusion: Histological and histochemical features of muscle of genetically homogenous SURF1-deficient LS were reproducible in detection of COX deficit. Minor muscle changes were not commonly present. Also, ultrastructural abnormalities were not a consistent feature. It should be emphasised that SURF1-deficient muscle assessed in the light and electron microscopy panel may be interpreted as normal if COX staining is not employed.

Leigh syndrome (LS), first described in 1951, is a severe neurodegenerative disease with characteristic neuropathological lesions located mainly in the basal ganglia, brain stem and sometimes other structures of central nervous system. ${ }^{1}$ Since the first description, hundreds of patients with LS-type brain changes have been reported. Various respiratory chain dysfunctions and/or the presence of different mitochondrial DNA mutations have been considered characteristic for all LS patients. ${ }^{2}$

The SURF1 gene discovered in 1998 is the first nuclear gene for which the association of its mutations with deficiency of respiratory chain complex IV (cytochrome $c$ oxidase $(\mathrm{COX})$ ) has been confirmed in humans. ${ }^{3}$ The SURF1 mutations were found invariably and almost exclusively in patients with generalised COX-deficit coexistent with LS features. Nearly 60 such patients and over 35 different mutations have been reported so far in the literature. ${ }^{5-32}$ SURF1 encodes for one of several proteins involved in proper assembly of the active COX complex.

Despite numerous detailed reports in muscle pathology in many different mitochondrial disorders $^{33}{ }^{34}$ the character of skeletal muscle lesions in SURF1-deficient LS has not been precisely described to date. In order to establish if there are any lesions of skeletal muscle specific for the SURF1 gene mutated patients, we summarised results of muscle biopsy in 21 patients with confirmed SURF1 gene mutations. Our analysis also includes data on 15 patients available from the literature (patients were of English, French and Czech nationality).

\section{PATIENTS AND METHODS}

Retrospective pathological investigations were performed in all children with the diagnosis of LS established at our mitochondrial centre during the period 1994-2005 in whom genetic molecular studies eventually revealed the presence of SURF1 gene mutations.

Skeletal muscle samples from 21 patients from 20 unrelated Polish families (11 boys and 10 girls, aged from 9 months to 12 years) were reassessed by light and/or electron microscopy.

Commonly accepted clinical criteria was applied for establishing the LS diagnosis in the patients. ${ }^{35}$ Biochemical assays of muscle homogenates showed a decrease in activity of complex IV of the respiratory chain and an increase in activity of citric synthase (CS). Molecular analysis of the SURF1 gene revealed the presence of the c.841delCT (formerly c.845delCT) mutation in all patients studied. Twelve patients were homozygous for this mutation, and the remaining seven were compound heterozygous. Clinical, biochemical and molecular characteristics of the patients are presented in table 1 , and were also published in part previously. ${ }^{13} 273637$

Skeletal muscle was obtained by open surgical biopsy of the vastus lateralis as a diagnostic procedure. Pathological studies comprised light microscopic assessment of frozen sections stained online under the BMJ Journals unlocked scheme, see http:// jcp.bmj.com/info/unlocked.dt 
Table 1 Clinical and molecular characteristics of 21 Polish Leigh syndrome (LS) patients with SURF1 gene mutations

\begin{tabular}{|c|c|c|c|c|c|c|c|}
\hline $\begin{array}{l}\text { Patient } \\
\text { no. }\end{array}$ & $\begin{array}{l}\begin{array}{l}\text { Age at diagnosis } \\
\text { (year of birth) }\end{array} \\
2 \text { years (1987) }\end{array}$ & $\begin{array}{l}\text { Clinical symptoms } \\
4 \text { months: motor regression, } \\
\text { floppiness, bulbar symptoms, } \\
\text { hirsutism, lactic acidaemia }\end{array}$ & Brain imaging, autopsy & $\begin{array}{l}\text { Complex IV } \\
\text { activity } \\
\text { (\% citric } \\
\text { synthase) }\end{array}$ & $\begin{array}{l}\begin{array}{l}\text { Citric synthase activity } \\
\text { (nmol/min/g protein) }\end{array} \\
70.4\end{array}$ & \multicolumn{2}{|c|}{$\begin{array}{l}\text { Presence of c. } 841 \text { delCT SURF1 } \\
\text { mutation at both alleles*/ }\end{array}$} \\
\hline 2 & 7 years (1987) & $\begin{array}{l}12 \text { months: trembling, uncertain } \\
\text { gait, myoclonic jerks, strabismus }\end{array}$ & $\begin{array}{l}\text { MRI: hyperintensive signals } \\
\text { at lenticular nuclei areas }\end{array}$ & 5.7 & 146 & c.841delCT & + \\
\hline 4 & 3.5 years (1989) & $\begin{array}{l}5 \text { months: failure to thrive, } \\
\text { floppiness, nystagmus, irregular } \\
\text { ventilation, trembling, hirsutism. } \\
\text { LS diagnosed at autopsy of } \\
\text { older brother }\end{array}$ & & 9.6 & 311 & c.841delCT & c.841delCT \\
\hline 6 & 6.5 years $(1990)$ & $\begin{array}{l}16 \text { months: speech difficulties, } \\
\text { hypotonia, nystagmus, motor } \\
\text { regression. LS diagnosed at } \\
\text { autopsy of sibling } \\
\text { (see patient 11) }\end{array}$ & & 7.4 & 86 & c.841delCT & + \\
\hline 7 & 3.75 years $(1990)$ & $\begin{array}{l}2 \text { years: difficulty in walking and } \\
\text { speaking, failure to thrive, } \\
\text { strabismus, hirsutism, } \\
\text { hyperventilation episodes; CT of } \\
\text { older brother: hypodense areas } \\
\text { at LS typical localisation }\end{array}$ & & 8.4 & 121.7 & c.841delCT & c.841delCT \\
\hline 8 & 3 years (1990) & $\begin{array}{l}12 \text { months: failure to thrive, } \\
\text { floppiness, hirsutism, irregular } \\
\text { respiration. CT and autopsy of } \\
\text { older sister revealed typical LS } \\
\text { changes }\end{array}$ & & NA & NA & c.841delCT & c.841delCT \\
\hline 11 & 10 years (1993) & $\begin{array}{l}16 \text { months: nystagmus, speech } \\
\text { and walking difficulties. Died at } \\
\text { age of }>10 \text { years }\end{array}$ & $\begin{array}{l}\text { At autopsy: spongiform } \\
\text { lesions; vascular } \\
\text { proliferation and neuronal } \\
\text { loss in mesencephalon, } \\
\text { diencephalon, medulla, and } \\
\text { white matter of cerebellum }\end{array}$ & $<3.0$ & 104.1 & c.841delCT & + \\
\hline 12 & 1.75 years (1994) & $\begin{array}{l}9 \text { months: hypotonia, floppiness, } \\
\text { failure to thrive, vomiting, tremor }\end{array}$ & & NA & NA & c.841delCT & c.841delCT \\
\hline 13 & 2 years (1995) & $\begin{array}{l}19 \text { months: tremor, eye } \\
\text { movement dissociation, } \\
\text { dystonia, irregular breathing }\end{array}$ & $\begin{array}{l}\text { CT: Symmetric hypodense } \\
\text { areas of basal ganglia }\end{array}$ & 6.2 & 194.9 & c.841delCT & c.841delCT \\
\hline 14 & 3 years (1996) & $\begin{array}{l}12 \text { months; floppiness, irregular } \\
\text { respiration, eye movement } \\
\text { dissociation, strabismus, } \\
\text { hirsutism }\end{array}$ & $\begin{array}{l}\text { MRI at } 2.5 \text { years: symmetric } \\
\text { hyperintensive signals in } \\
\text { basal ganglia }\end{array}$ & 3.7 & 111.4 & c.841delCT & + \\
\hline 15 & 2.75 years (1997) & $\begin{array}{l}4 \text { months: motor regression, } \\
\text { failure to thrive, floppiness, } \\
\text { tremor, hirsutism, lactic } \\
\text { acidaemia }\end{array}$ & & 5.3 & 112.7 & c.841delCT & c.841delCT \\
\hline 16 & 9 months (1997) & $\begin{array}{l}2 \text { months: floppiness, vomiting, } \\
\text { irregular respiration, eye } \\
\text { dissociation, ptosis, hirsutism. } \\
\text { LS in older brother }\end{array}$ & $\begin{array}{l}\text { MRI at } 4 \text { years: symmetric } \\
\text { hyperintensive signals in } \\
\text { basal ganglia, brain atrophy }\end{array}$ & 3.6 & 223 & c.841delCT & c.841delCT \\
\hline 17 & 1.5 years (1997) & $\begin{array}{l}7 \text { months; failure to thrive, } \\
\text { vomiting, hypotonia, hirsutism, } \\
\text { strabismus, lactic acidaemia }\end{array}$ & & 5.8 & 174 & c.841delCT & c.841delCT \\
\hline
\end{tabular}


Table 1 Continued

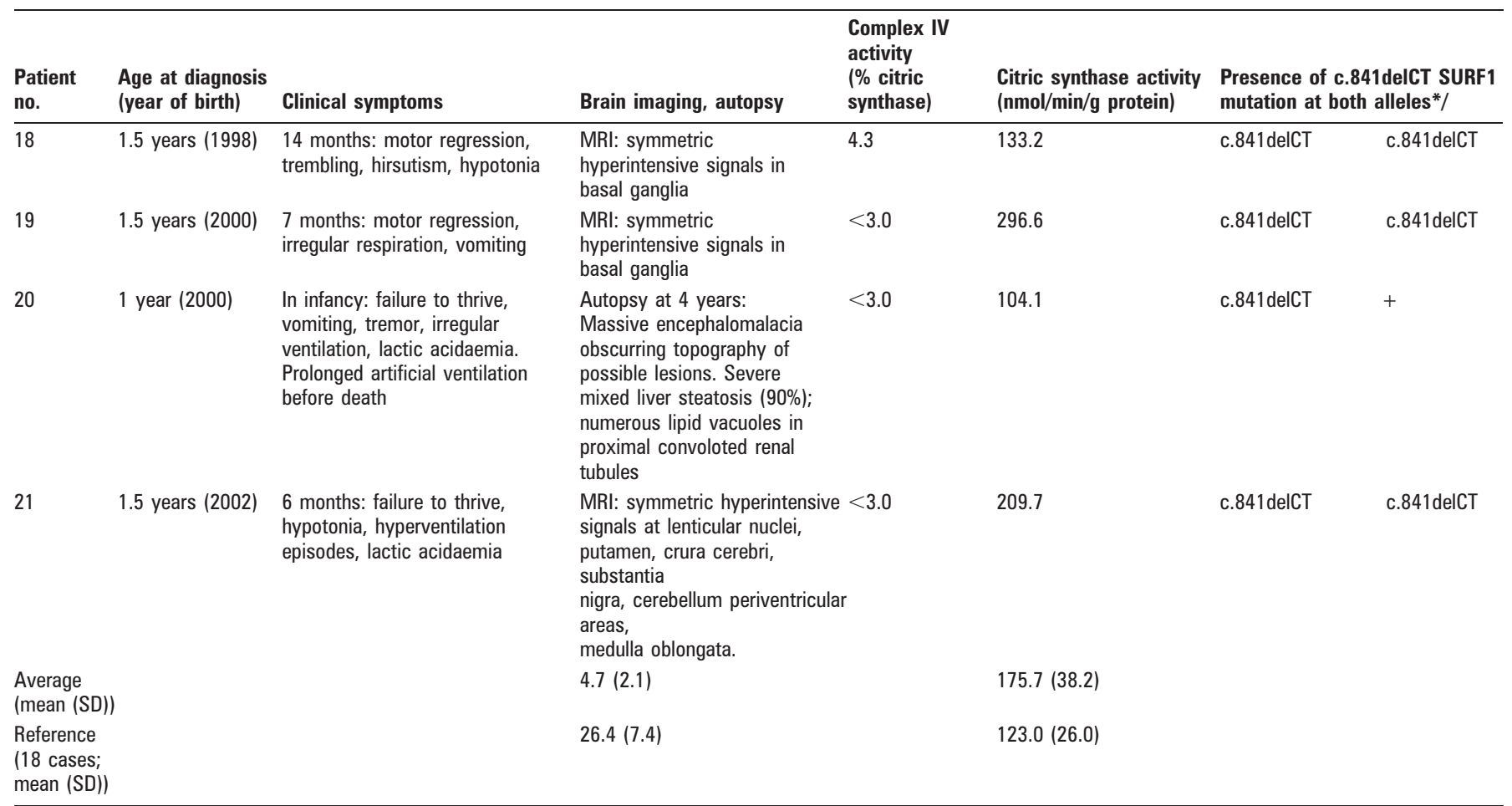

CT, computer tomography; MRI, magnetic resonance imaging; NA, not analysed; +, presence of non-c.841delCT mutations. ${ }^{132736}$

with haematoxylin and eosin (H\&E), modified Gomori trichrome, oil red $\mathrm{O}$, succinate dehydrogenase (SDH), COX, $\mathrm{NADH}$ dehydrogenase, acid phosphatase, and myosin ATPase at $\mathrm{pH}$ 4.3, 4.6, and 9.4. Assessment was performed in parallel with ongoing mitochondrial biochemical and clinical diagnostics.

For ultrastructural study the tissue was fixed in $2.5 \%$ cold glutaraldehyde for $1 \mathrm{~h}$, washed in cacodylate buffer, post-fixed in $1 \%$ osmium tetroxide, dehydrated in graded alcohols and embedded in Epon 812 resin (DDSA, MNA; Serva, Heidelberg, Germany). The semi-thin sections were stained with toluidine blue to identify the region for ultrastructural study. Transverse and longitudinal sections were examined. Ultra-thin sections were counterstained with uranyl acetate and lead citrate and examined in a JEOL 1500 electron microscope (Tokyo, Japan). All muscle samples were processed for electron microscopy (EM) in the years 1994-2005.

The study protocol has been accepted by the institutional Childrens' Memorial Health Institute Bioethical Commission.

\section{RESULTS}

Muscle light microscopy and electron microscopy results obtained from the individual patients are shown in the table 2.

Histological and histochemical pattern of muscle changes were similar in all children with SURF1 gene mutations. Diffuse decreased activity or total deficit of COX activity was found in all patients (fig 1A,B).

In most children, COX deficit was accompanied by slight to moderate accumulation of lipids in muscle (fig 1C). Only three patients demonstrated no lipid increase. Half of the patients showed mild variability in muscle fibre diameter (fig 1D). Predominance of type 1 fibres was not found in the muscle with the exception of three cases. One case showed mild tendency for fibre type grouping. This phenomenon (not seen in any other patient) was considered unrelated to the primary molecular defect. No patient showed presence of RRF or increase of succinate dehydrogenase activity in muscle.

Ultrastructural examination of skeletal muscles biopsies revealed a spectrum of morphological abnormalities consisting mainly of more or less detectable mitochondrial alterations (fig 2). In a majority of patients (12 of 19 examined cases), several muscle fibres demonstrated distinct subsarcolemmal accumulation of altered mitochondria (fig 2B,C). Frequently, the mitochondria were markedly enlarged or elongated (fig 2C,D) and exhibited dark matrix with densely packed, concentrically arranged lamellar cristae (fig 2D,E). Occasionally, the mitochondrial matrix displaced spaces with amorphous granular material and small, electron-dense, osmophilic granules (fig 2D). Extensive accumulation of lipid deposits occurred in association with normal and altered mitochondria (fig 2F,G). Some muscle fibres revealed alterations of myofibrils including their focal or widespread disorganisation and/or disruption (fig $2 \mathrm{~A}-\mathrm{H}, \mathrm{I}$ ). Moreover, the tubulofilamentous structures typical of cytoplasmic body formation and subsarcolemmal aggregation of concentric laminated bodies were also found in individual cases (fig $2 \mathrm{H}$ ).

Major changes in mitochondria on electron microscopy were not common in all SURF1-deficient LS patients, and were observed in a third of the cases (fig 3). The picture was normal in five cases and mild in two others.

No correlation was found between the electron microscopy findings and the light microscopy findings (ie, variability of fibre size), or with the clinical parameters (ie, age of biopsy and homozygous/heterozygous status of c.841delCT mutation).

A slightly significant correlation was found only between presence of lipid accumulation demonstrated by light and electron microscopy (Pearson test 0.39 ; $\mathrm{p}<0.05$ ).

\section{DISCUSSION}

SURF1-deficient LS presents a special sub-group of LS in which an as-yet unexplained homogeneity of changes in the brain ${ }^{36} 37$ 
Table 2 Histological, histochemical and electron microscopy findings in skeletal muscle of 21 children with Leigh syndrome (LS) and SURF1 gene mutation

\begin{tabular}{|c|c|c|c|c|c|c|c|c|c|c|}
\hline $\begin{array}{l}\text { Patient } \\
\text { no. }\end{array}$ & $\begin{array}{l}\text { Age at } \\
\text { biopsy } \\
\text { (years) }\end{array}$ & $\begin{array}{l}\text { Cox } \\
\text { deficiency }\end{array}$ & RRF & $\begin{array}{l}\text { Lipid } \\
\text { accumulation }\end{array}$ & $\begin{array}{l}\text { Other pathology of skeletal } \\
\text { muscle fibres }\end{array}$ & $\begin{array}{l}\text { Abnormal } \\
\text { MT* }^{*}\end{array}$ & $\begin{array}{l}\text { Lipid } \\
\text { droplets }\end{array}$ & $\begin{array}{l}\text { Miofibrile } \\
\text { loss }\end{array}$ & $\begin{array}{l}\text { Cytoplasmic } \\
\text { bodies }\end{array}$ & $\begin{array}{l}\text { Concentric } \\
\text { laminated } \\
\text { bodies }\end{array}$ \\
\hline 1 & 2 & ++ & - & + & Variability of diameter & + & - & - & - & - \\
\hline 2 & 7 & ++ & - & ++ & Not found & $+/-$ & + & + & - & - \\
\hline 3 & 12 & ++ & - & ++ & Mild variability of diameter & - & + & + & - & - \\
\hline 4 & 3.5 & NA & - & NA & Not found & + & - & + & - & - \\
\hline 5 & 4 & NA & - & + & Not found & - & - & + & - & - \\
\hline 6 & 6.5 & ++ & - & - & Variability of diameter & ++ & - & - & + & - \\
\hline 7 & 3.75 & ++ & - & + & Not found & - & + & - & - & - \\
\hline 8 & 3 & NA & - & - & Not found & NA & NA & NA & NA & NA \\
\hline 9 & 3 & + & - & ++ & Not found & + & - & - & - & - \\
\hline 10 & 2.5 & ++ & - & + & Mild variability of diameter & ++ & + & + & - & + \\
\hline 11 & 10 & ++ & - & + & $\begin{array}{l}\text { Variability diameter, fibre type } \\
\text { grouping }\end{array}$ & - & + & - & - & - \\
\hline 12 & 1.75 & + & - & + & Not found & $+1-$ & + & + & - & - \\
\hline 13 & 2 & ++ & - & ++ & Predominance of type I fibres & ++ & + & - & - & - \\
\hline 14 & 3 & ++ & - & - & Mild interstitial fibrosis & + & + & - & - & - \\
\hline 15 & 2.75 & ++ & - & + & Predominance of type I fibres & - & - & + & - & - \\
\hline 16 & 0.75 & ++ & - & + & Predominance of type I fibres & ++ & + & - & - & - \\
\hline 17 & 1.5 & + & - & ++ & Variability of diameter & + & - & + & - & - \\
\hline 18 & 1.5 & + & - & ++ & Not found & + & + & - & - & - \\
\hline 19 & 1.5 & + & - & ++ & Mild variability of diameter & - & + & - & - & - \\
\hline 20 & 1 & ++ & - & - & Mild variability of diameter & - & - & - & - & - \\
\hline 21 & 1.5 & + & - & ++ & Mild variability of diameter & NA & NA & NA & NA & NA \\
\hline
\end{tabular}

Light microscopy and electron microscope findings: +/- mild changes; + moderate changes; ++ severe changes; - no changes; ${ }^{*}$ Mitochondrial (MT) ultrastructure abnormalities: +++ : increase in mitochondrial number, changes in size, shape, and presence of electron dense inclusions; ++ : increase in mitochondrial number, variation in size and shape; +: increase in mitochondrial number, slight variation in size and shape; $+/-$ : slight increase in mitochondrial number.

COX, cytochrome c oxidase; NA, not analysed; RRF, ragged red fibre.

co-exist with a homogeneous pathogenetic molecular background. The exact role of the SURF1 protein has not been fully elucidated, but it is well known that without its contribution the COX complex is assembled improperly and functionally impaired. ${ }^{38-41}$ SURF1 acts in the early steps of COX assembly and may promote the association of the mitochondrially-encoded subunit COXII with the COXI-COXIV-COXV subassembly. There is a paucity of data on the typical morphological features of skeletal muscle in SURF1-deficient LS patients. In the majority of publications referring to SURF1 gene mutations, skeletal muscle morphology is not included or it is limited to histochemical confirmation of COX deficit. $.^{12} 16192122-242628$ Only anecdotal
Figure 1 Histochemical and histological findings in the muscle of patients with Leigh syndrome associated with $\mathrm{c}$. 841 delCT SURF1 gene mutation. A. Total diffuse cytochrome $c$ oxidase (COX) deficit. B. Reference positive COX reaction (patient with encephalopathy of unknown cause examined in the same batch). C. Moderate lipid increase in muscle fibres. D. Variability of muscle fibre diameter.
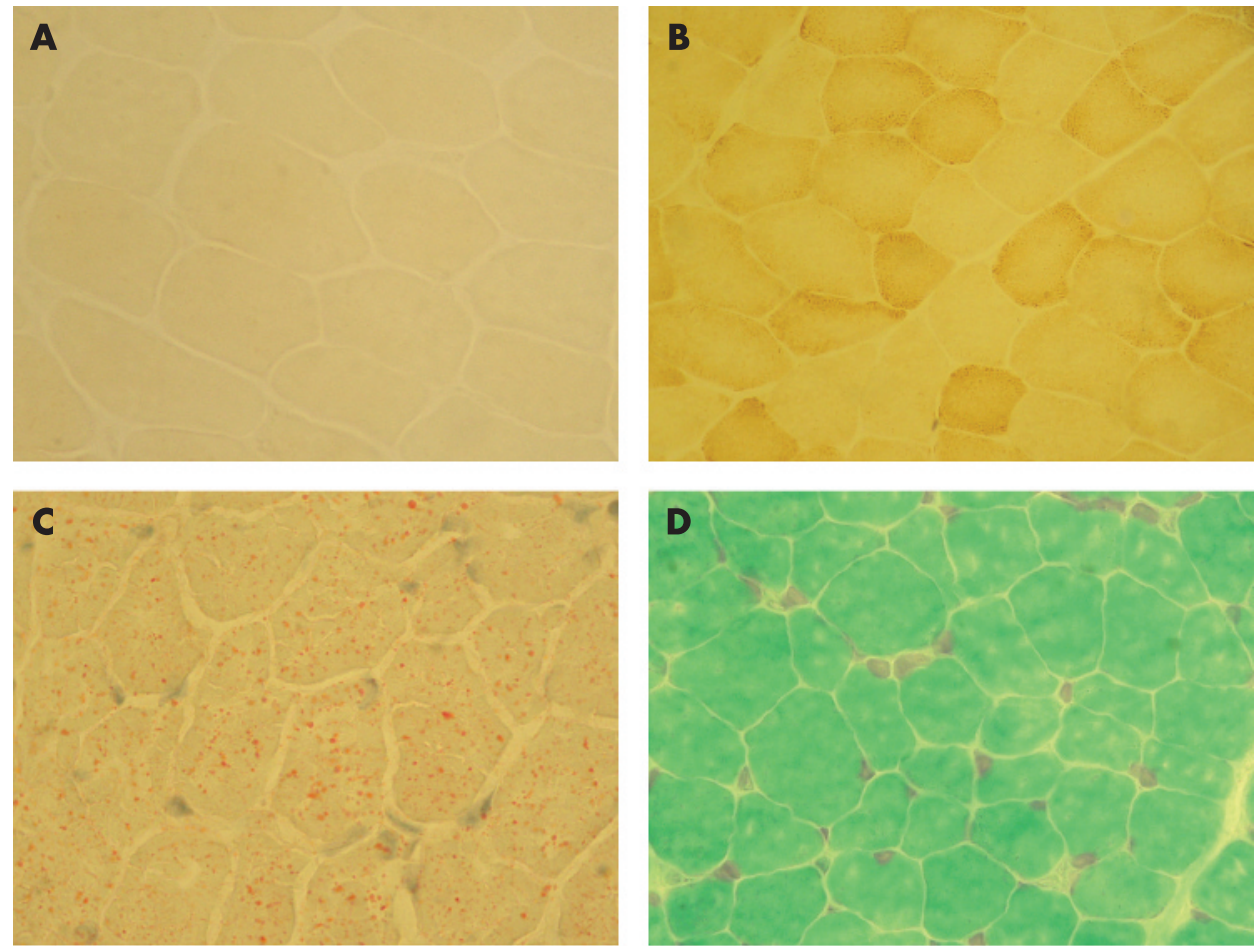
Figure 2 Ultastructural findings in the muscle of patients with Leigh syndrome associated with c. 841delCT SURF1 gene mutation. In a majority of patients (12 of 19 examined cases), several muscle fibres demonstrated distinct subsarcolemmal accumulation of altered mitochondria $(B, C)$. Frequently, the mitochondria were markedly enlarged or elongated $(C, D)$ and exhibited dark matrix with densely packed, concentrically arranged lamellal cristae (D, E). Occasionally, the mitochondrial matrix displaced spaces with amorphous granular material and small, electrondense, osmophilic granules (D). Extensive accumulation of lipid deposits occurred in association with normal and altered mitochondria (F, G). Some muscle fibres revealed alterations of myofibrils including their focal or widespread disorganisation and/or disruption $(A, H, I)$. Moreover, the tubulofilamentous structures typical of cytoplasmic body formation and subsarcolemmal aggregation of concentric laminated bodies were also found in individual cases (H). Original magnification: $A, \times 12000$; $\mathrm{B}, \mathrm{C}, \mathrm{F}, \times 7500 ; \mathrm{D}, \mathrm{G}, \times 15000 ; \mathrm{E}$, $\times 10000 ; H, \times 20000 ; \mathrm{I}, \times 3000$.
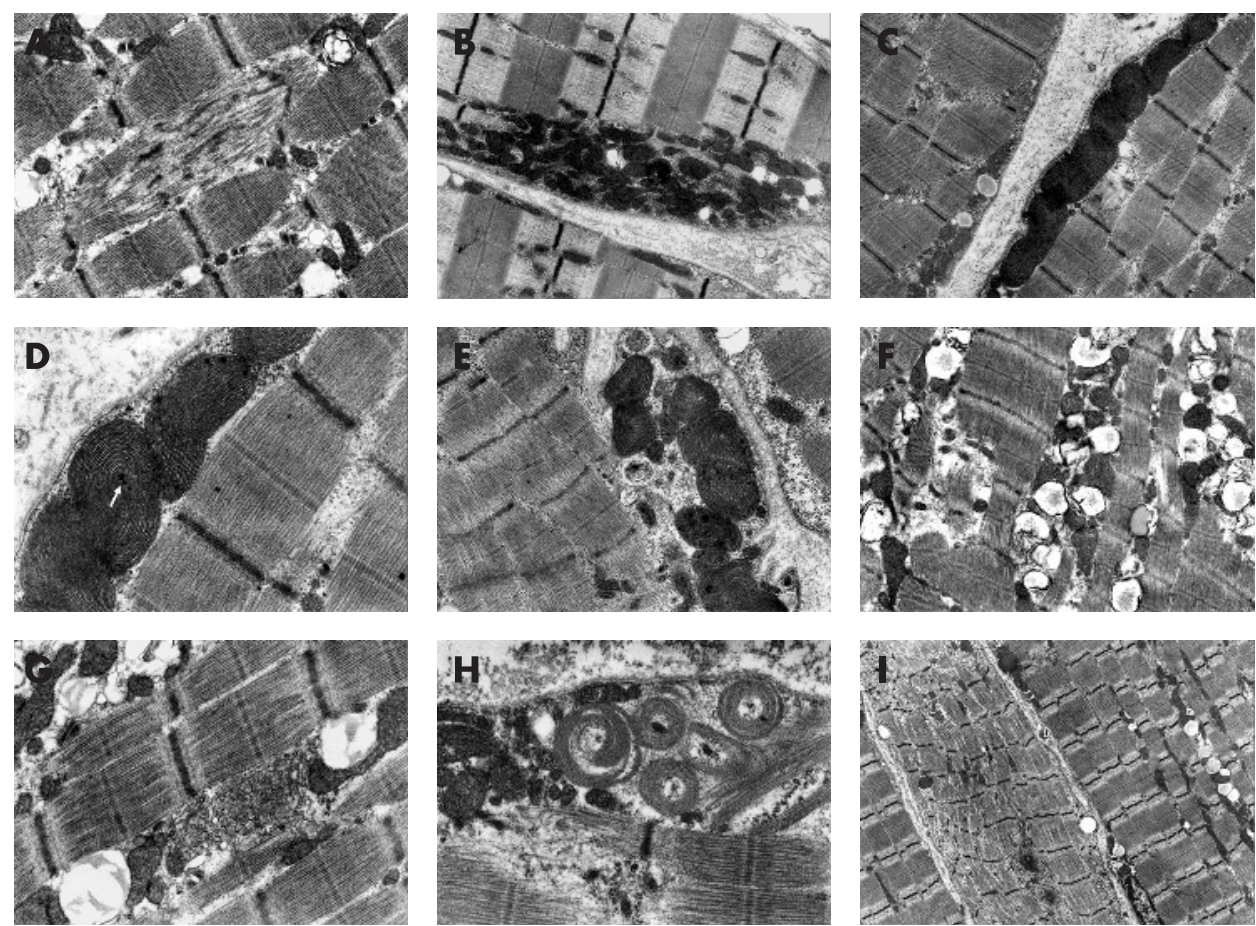

reports about light microscopy findings in these 15 single case reports are available (table 3 ).

The experimental model of SURF1-deficient mice presented with profound and isolated defect of COX activity, reduced histochemical reaction of COX, and mitochondrial proliferation. $^{47}$

The cohort reported in this study was especially homogenous, carring the same c.841delCT mutation on both or one of alleles of the SURF1 gene. This mutation is frequent among Polish, Czech and probably other Slavonic populations. ${ }^{13} 1517272836$ Here, we demonstrate that muscle biopsy of patients carrying the c.841delCT SURF1 gene mutation show features that are similar to those found in the knock-out mice. ${ }^{47}$ In a manner akin to the results observed in the mouse model, all but two patients did not show a predominance of type I fibres (table 2). This is in agreement with the findings previously reported for cases with

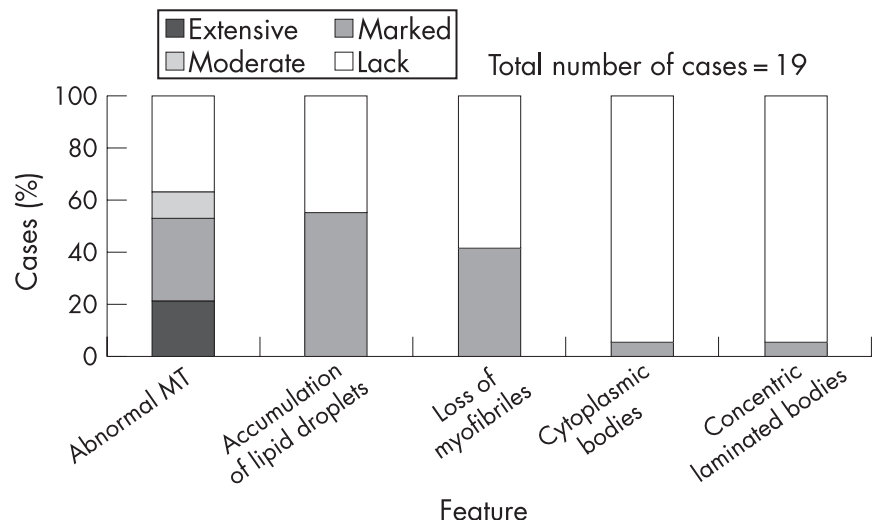

Figure 3 Distribution and frequency of various ultrastructural changes among 21 muscles of patients with SURF1-deficient Leigh syndrome.
SURF1 gene mutations (table 3). By contrast, this finding is considered frequent in the mitochondrial myopathies in general. $^{48}$

Among other minor features of the mitochondrial lesions lipid accumulation was seen more frequently in our material, and was present in 14 examined SURF1-LS specimens (table 2). Similarly the lipid accumulation was also commonly found in the SURF1-deficient LS muscles described earlier (table 3). The next quite frequent feature found in the studied material was variability of fibre size, present in nine muscle samples. Some degree of this abnormality was also mentioned in the previously reported cases (table 3 ). In general, the muscle morphology of these patients does not differ significantly from our findings. The so-called "Polish" SURF1 mutation of c.841delCT, the most prevalent in our patients, was not found in any of the described cases.

It is important to emphasise that the presence of RRFs in the muscle, characteristic of mtDNA encoded mitochondrial myopathies, was extremely rare if not non-existent in the nuclearly encoded SURF1-LS muscle specimens, particularly in those carrying c.841delCT mutations. There is only one description of LS with SURF1 mutations showing RRFs in a patient carrying two protein truncated mutations (table 3 ). ${ }^{25}$ RRFs were also not detected in the muscle of SURF1-deficient knock-out mice. ${ }^{47}$

However, the signs of increased mitochondria number seem not to be rare in the SURF1-deficient muscle. Subsarcolemmal $\mathrm{NADH}$-tetrazolium positive rims, ${ }^{42}$ or intense subsarcolemmal $\mathrm{SDH}$ staining ${ }^{45}$ suggested incipient mitochondrial proliferation. Increased SDH reaction was also seen in the animal knock-out model of the disease. ${ }^{47}$ These reactions were negative in all our muscle specimens with homozygous and heterozygous c.841delCT SURF1 gene mutation.

Ultrastructural assessment of knock-out mice revealed marked subsarcolemmal accumulation of enlarged mitochondria. Our ultrastructural findings in the affected human muscles 
Table 3 Muscle histology and histochemistry of patients with SURF1 gene mutation found in published case reports

\begin{tabular}{|c|c|c|c|}
\hline Muscle histology and histochemistry & Age at biopsy & SURF1 mutations & References \\
\hline $\begin{array}{l}\text { COX deficit, remarkable lipid accumulation; subsarcolemmal increase } \\
\text { of NADH activity }\end{array}$ & 5 years & $\begin{array}{l}\text { A patient from Tirani's SURF1-deficient } \\
\text { complementary group with "atypical" LS }\end{array}$ & $\begin{array}{l}\text { Tiranti et } a l_{,}^{3} \text { Tirani et } a l_{,}^{43} \\
\text { Angelini et } a l^{42} \text { and Munaro et } \\
a l^{44}\end{array}$ \\
\hline COX partial deficit, slight subsarcolemmal increase of SDH activity & Not reported & c.312del10insAT//c.567insCAGG & Sue et $a l^{9}$ and Van Coster et $a l^{45}$ \\
\hline Normal findings & 1.5 years & c.589insCTGC//c.702C >T & $\begin{array}{l}\text { Poyau et } a l^{8} \text { and Collombet et } \\
a l^{46}\end{array}$ \\
\hline COX deficit, subsarcolemmal increase of SDH and NADH activity & 4 years & c.312del10insAT//c.385G >A & $\begin{array}{l}\text { Poyau et } a l^{\beta} \text { and Collombet et } \\
a l^{46}\end{array}$ \\
\hline Normal findings (COX not assessed) & 3 years & c.312del10insAT//c.385G $>$ A & $\begin{array}{l}\text { Poyau et } a l^{8} \text { and Collombet et } \\
a l^{46}\end{array}$ \\
\hline Variability in fibre size & 1.5 years & c.790delAG//c.820T $>$ G & Teraoka et $a l^{7}$ \\
\hline COX deficit, lipid accumulation & 2 years & c.240+1G > T// c.531_534delAAAT & Bruno et $a l^{18}$ \\
\hline COX deficit slight variability of fibre diameter, several hypotrophic fibres & 5 years & Homozygous $082 \mathrm{X}$ & Santoro et $a l^{10}$ \\
\hline Lipid accumulation, atrophy of type II fibres & 2.5 years & Homozygous c.790_791delAG & Rahman et $a l^{14}$ \\
\hline COX deficit & $<2$ years & c.312del10insAT//c.688C $>T$ & Tay et $a l^{25}$ \\
\hline COX deficit, type I fibres atrophy & $<2$ years & Homozygous c.834G $>$ A & Tay et $a l^{25}$ \\
\hline COX deficit, mild non-specific changes & $<2$ years & As above (siblings) & Tay et $a l^{25}$ \\
\hline COX deficit; several RRFs & $<2$ years & c.312del10insAT//c 822_824dupTACAT & Tay et $a l^{25}$ \\
\hline COX deficit & Not done & c.608T $>$ C//c.675_692del18 & Sacconi et $a l^{20}$ \\
\hline Normal findings (including COX staining)* & 3 years & Homozygous c. $867 \mathrm{G}>\mathrm{A}$ & Van Riesen et $a l^{29}$ \\
\hline
\end{tabular}

${ }^{*}$ Severe isolated COX deficiency detected by biochemical assay.

COX, cytochrome c oxidase; LS, Leigh syndrome; RRF, ragged red fibre; SDH, succinate dehydrogenase.

were comparable to the animal model, also suggesting an increased number of mitochondria in several cases, but not in all of them. In the literature there is only scant information on the ultrastructure of human SURF1-deficient LS muscles. An exception is one case with COX-deficient Leigh syndrome reported in $1977 .{ }^{49}$ Thirty years later, a homozygous c.370C $>$ A SURF1 gene mutation was identified in this patient. ${ }^{50}$ The dominant ultrastructural feature of this case was enlarged mitochondria of bizarre shape and various size and form, aggregated in juxtanuclear and subsarcolemmal regions. The mitochondria contained an excessive number of irregularly arranged and distorted cristae. Fine granular electron-dense material was seen in the matrix, but paracristalline inclusions and large spherical dense bodies were absent. Myofibrils and myofilaments were preserved. Lipid droplets were seen in association with abnormal mitochondria. ${ }^{49}$

In agreement with this description, our ultrastructural study confirms that SURF1 mutations may be associated with detectable structural manifestations of mitochondrial involvement. However, approximately a third of our SURF1-deficient muscle specimens (and the remaining two reports of ultrastructural findings in the literature $)^{78}$ did not demonstrate any ultrastructural anomalies of the mitochondria.

\section{Take-home messages}

- SURF1-deficient skeletal muscle of patients with Leigh syndrome (LS) shows a reproducible and characteristic pattern of changes in light and electron microscopy that are potentially helpful in diagnosis.

- It should be kept in mind that those changes are not specific.

- Diffuse cytochrome c oxidase (COX) deficit remains the salient feature, and muscle may be interpreted as normal if the histochemical panel does not include COX reaction. The role of an experienced pathologist at this step of LS investigation is therefore important.
Ultrastructural abnormalities found by us were similar to these seen in the animal model of the disease. ${ }^{47}$ However it is not possible to identify any morphological or ultrastructural features that are exclusively and commonly present in muscles with SURF1 mutations. Our results and those described in the literature data indicate that mitochondrial abnormalities can not be considered specific for the SURF1-deficient LS as it is unanimously accepted for all mitochondrial disorders, including those associated with mtDNA mutations.

On the basis of our study we propose that a diffuse deficit of COX in the muscle by histochemical staining, in particular in a child of Polish origin with a clinical phenotype of LS, should prompt direct molecular testing for the c.841delCT mutation in the SURF1 gene. In our experience the contribition of an experienced clinical pathologist was very useful at this step of diagnosis of mitochondrial disorders in children. ${ }^{51}$ Additional histological features such as lack of RRFs and normal fibre size proportion, presence of lipid accumulation of mild to remarkable degree and fibre size variability had only limited diagnostic value in differential diagnosis of LS associated with SURF1 gene mutations.

The electron microscopy showed no abnormalities in a third of our SURF1-deficient muscle biopsies, as in three of four descriptions found in the literature. ${ }^{7} 86$ This demonstrates that the diagnostic value of minor ultrastructural abnormalities is disputable, especially in children with a suspicion of mitochondrial disorder. ${ }^{52} 53$

In conclusion, diffuse COX deficit in muscle biopsies is the only reproducible pathological finding of patients with LS. It should be emphasised that samples from LS patients solely assessed by means of microscopy or by histochemistry using a panel not including COX may be misinterpreted as normal.

Acknowledgements: The authors thank Professor Ewa Pronicka for inspiration and critical remarks.

Funding: This work was supported by MitoNet, the Polish Mitochondrial Network (http://mitonet.pl).

Competing interests: None declared. 


\section{REFERENCES}

1. Leigh D. Subacute necrotizing encephalomyelopathy in an infant. J Neurol Neurosurg Psychiat 1951;14:216-21.

2. Di Donato $\mathbf{S}$. Disorders related to mitochondrial membranes: pathology of the respiratory chain and neurodegeneration. J Inherit Metab Dis 2000:23:247-63.

3. Tiranti V, Hoertnagel K, Carrozo R, et al. Mutations of SURF-1 in Leigh disease associated with cytochrome $c$ oxidase deficiency. Am J Hum Genet 1998;63:1609-21.

4. Zhu Z, Yao J, Johns T, et al. SURF1, encoding a factor involved in the biogenesis of cytochrome $c$ oxidase, is mutated in Leigh syndrome. Nat Genet 1998;20:337-43.

5. Tirani V, Jaksch M, Hofmann S, et al. Loss-of-function mutations of SURF-1 are specifically associated with Leigh syndrome with cytochrome $c$ oxidase deficiency. Ann Neurol 1999;46:161-6.

6. Coenen MJH, van den Heuvel LP, Nijtmans LGJ, et al. SURFEIT-1 gene analysis and two-dimensional blue native gel electrophoresis in cytochrome $c$ oxidase deficiency. Bioch Biophys Res Commun 1999;265:339-44.

7. Teraoka M, Yokoyama Y, Ninomiya S, et al. Two novel mutations of SURF1 in Leigh syndrome with cytochrome $c$ oxidase deficiency. Hum Genet 1999;105:560-3.

8. Poyau A, Bucht K, Bouzidi MF, et al. Missense mutations in SURF1 associated with deficient cytochrome $c$ oxidase assambly in Leigh syndrome patients. Hum Genet 2000:106:194-205

9. Sue CM, Karadimas C, Checcarelli N, et al. Differential features of patients with mutations in two COX assembly genes, SURF-1 and SCO2. Ann Neurol 2000:47:589-95.

10. Santoro L, Carrozzo R, Malandrini A, et al. A novel SURF1 mutation results in Leigh syndrome with peripheral neuropathy caused by cytochrome $c$ oxidase deficiency. Neuromuscular Dis 2000;10:450-3.

11. Pequignot MO, Dey R, Zeviani M, et al. Mutations in the SURF1 gene associated with Leigh syndrome and cytochrome $c$ oxidase deficiency. Hum Mut 2001;17:37581 .

12. Pequignot M0, Desguerre I, Dey R, et al. New splicing-site mutations in the SURF1 gene in Leigh syndrome. J Biol Chem 2001;276:15326-9.

13. Piekutowska-Abramczuk D, Popowska E, Pronicka E, et al. SURF1 gene mutations in Polish patients with COX-deficient Leigh syndrome. J App/ Genet 2001;42:103-8.

14. Rahman S, Brown RM, Chong WK, et al. A SURF1 gene mutation presenting as isolated leukodystrophy. Ann Neurol 2001;49:797-800.

15. Williams SL, Taanman J-W, Hansikova H, et al. A novel mutation in SURF1 causes skipping of exon 8 in a patient with cytochrome $c$ oxidase-deficient Leigh syndrome and hypertrichosis. Mol Genet Metab 2001;73:340-3

16. Von Kleist-Retzow J-Ch, Yao J, Taanman J-W, et al. Mutations in SURF1 are not specifically associated with Leigh syndrome. J Med Genet 2001;38:109-13.

17. Capkova M, Hansikova $\mathrm{H}$, Godinot $\mathrm{C}$, et al. A new missense mutation of $574 \mathrm{C}>\mathrm{T}$ in the SURF1 gene - biochemical and molecular genetic study in seven children with Leigh syndrome (in Czech). Cas Lek Cesk 2002;141:636-41.

18. Bruno C, Biancheri R, Garavaglia B, et al. A novel mutation in the SURF1 gene in a child with Leigh disease, peripheral neuropathy, and cytochrome-c oxidase deficiency. J Child Neurol 2002;17:233-6.

19. Ogawa $\mathbf{Y}$, Naito $E$, Ito $M$, et al. Three novel SURF-1 mutations in Japanese patients with Leigh syndrome. Pediatr Neurol 2002:26:196-200.

20. Sacconi S, Salviati L, Sue CM, et al. Mutation screening in patients with isolated cytochrome $c$ oxidase deficiency. Ped Res 2003:53:224-30.

21. Rossi A, Biancheri $\mathrm{R}$, Bruno $\mathrm{C}$, et al. Leigh syndrome with COX deficiency and SURF1 gene mutations: MR imaging findings. Am J Neuroradiol 2003;24:1188-91.

22. Moslemi A-R, Tulinius M, Darin N, et al. SURF1 gene mutations in three cases with Leigh syndrome and cytochrome $c$ oxidase deficiency. Neurology 2003;61:991-3.

23. Head RA, Brown RB, Brown GK. Diagnostic difficulties with common SURF1 mutations in patients with cytochrome oxidase-deficient Leigh syndrome. $J$ Inherit Metab Dis 2004;27:57-65.

24. Salviati L, Freehauf C, Sacconi S, et al. Novel SURF1 mutation in a child with subacute encephalopathy and without the radiological features of Leigh syndrome. Am J Med Genet 2004;128A:195-8.

25. Tay SK, Sacconi S, Akman HO, et al. Unusual clinical presentations in four cases of Leigh disease, cytochrome oxidase deficiency, and SURF1 gene mutations. J Child Neurol 2005;20:670-4.

26. Monnot S, Chabrol B, Cano A, et al. Syndrome de Leigh avec deficit en cytochrome $C$ oxidase lie a une mutation homozygote du gene SURF1 (in French). Arch Pediat 2005;12:568-71

27. Bohm M, Pronicka E, Karczmarewicz E, et al. Retrospective, multicentric study of 180 children with cytochrome $c$ oxidase deficiency. Ped Res 2006;59:21-6.

28. Ostergaard E, Bradinova I, Ravn SH, et al. Hypertrichosis in patients with SURFmutations. Am J Med Genet 2005:138A:384-8.
29. Van Riesen AKJ, Antonicka H, Ohlenbusch A, et al. Maternal segmental disomy in Leigh syndrome with cytochrome $c$ oxidase deficiency caused by homozygous SURF1 mutation. Neuropediatrics 2006;37:88-94.

30. Coenen MJH, Smeitink JAM, Pots JM, et al. Sequence analysis of the structural nuclear encoded subunits and assembly genes of cytochrome $c$ oxidase in a cohort of 10 isolated complex IV-deficient patients revealed five mutations. J Child Neurol 2006;21:508-11.

31. Yang Y-I, Sun F, Zhang Y, et al. Clinical and laboratory survey of 65 Chinese patients with Leigh syndrome. Chinese Medical Journal 2006;119:373-7.

32. Yuksel A, Seven M, Cetincelik U, et al. Facial dysmorphism in Leigh syndrome with SURF-1 mutation and COX deficiency. Pediatr Neurol 2006;34:486-9.

33. Bourgeois J, Tarnopolski M. Pathology of skeletal muscle in mitochondrial disorder Mitochondrion 2004:4:441-52.

34. DiMauro S, Hirano M. Mitochondrial encephalomyopathies: an update. Neuromuscul Disord 2005:15:276-86

35. Rahman S, Blok R, Dahl H-H, et al. Leigh syndrome: clinical features and biochemical and DNA abnormalities. Ann Neurol 1996:39:343-51.

36. Pronicka E, Piekutowska-Abramczuk DH, Popowska E, et al. Compulsory hyperventilation and hypocapnia of patients with Surf-1 gene mutations as a cause of low serum bicarbonates. J Inherit Metab Dis 2001;24:717-14.

37. Pronicka E, Halikowski B. Metabolic acidosis versus a compensation of respiratory alkalosis in four children with Leigh disease. J Inherit Metab Dis 1984;7(Suppl 2):113-4.

38. Pecina P, Capkova M, Chowdhury SKR, et al. Functional alteration of cytochrome c oxidase by SURF1 mutations in Leigh syndrome. Bioch Biophys Acta 2003:1639:53-63.

39. Wasniewska M, Karczmarewicz E, Pronicki M, et al. Abnormal calcium homeostasis in fibroblasts from patients with Leigh disease. Biochem Biophys Res Commun 2001;283:687-93.

40. Pecina P, Houstkova $\mathrm{H}$, Hansikova $\mathrm{H}$, et al. Genetic defects of cytochrome $c$ oxidase assembly. Physiol Res 2004:53(Suppl 1):S213-23.

41. Pecina $\mathbf{P}$, Gnaiger $E$, Zeman J, et al. Decreased affinity for oxygen of xytochrome $c$ oxidase in Leigh syndrome caused by SURF1 mutations. Am J Physiol Cell Physiol 2004:287:C1384-8.

42. Angelini C, Bresolin N, Pergolo G, et al. Childhood encephalomyopathy with cytochrome $c$ oxidase deficiency, ataxia, muscle wasting, and mental retardation. Neurology 1986;36:1048-52

43. Tirani V, Munaro M, Sandona D, et al. Nuclear DNA origin of cytochrome $c$ oxidase deficiency in Leigh's syndrome: genetic evidence based on patient's-derived rho transformants. Hum Mol Genet 1995;4:2017-23

44. Munaro M, Tirani V, Sandona D, et al. A single cell complementation class in common to several casus of cytochrome $c$ oxidase defective Leigh's syndrome. Hum Mol Genet 1997;6:221-8.

45. Van Coster R, Lombes A, De Vivo, et al. Cytochrome $c$ oxidase-associated Leigh syndrome: phenotypic features and pathogenetic speculations. J Neurosci 1991; 104:97-111.

46. Collombet JM, Zabot MT, Vidailhet $M$, et al. Interet des fibroblasts cutanes en culture pour le diagnostic des cytopathies mitochondriales. A propos de cinq observations de deficit en cytochrome oxidase (in French). Pediatrie 1993;48:28795.

47. Agostino A, Invernizzi F, Tiveron C, et al. Constitutive knockout of Surf1 is associated with high embryonic lethality, mitochondrial disease and cytochrome $c$ oxidase deficiency in mice. Hum Mol Genet 2003:12:399-413.

48. Enns G, Hoppel C, Dearmond S, et al. Relationship of primary mitochondrial respiratory chain dysfunction to fiber type abnormal in skeletal muscle. Clin Genet 2005;68:337-48

49. Willems JL, Monnens LAH, Trijbels JMF, et al. Leigh's encephalopathy in a patients with cytochrome $c$ oxidase deficiency in muscle tissue. Pediatrics 1977:60:850-7.

50. Coenen MJH, Smeitink JAM, Farhoud MH, et al. The first patient diagnosed with cytochrome $c$ oxidase deficient Leigh syndrome: progress report. J Inherit Metab Dis 2006:29:213-13.

51. Vogel H. Mitochondrial myopathy and the role of the pathologist in the molecular era J Neuropathol Exp Neurol 2001;60:217-27.

52. Miles L, Wong BL, Dinopoulos A, et al. Investigation of children for mitochondriopathy confirms need for strict patient selection, improved morphological criteria, and better laboratory methods. Hum Pathol 2006;37:173-84.

53. Uusimaa J, Remes AM, Rantala $\mathrm{H}$, et al. Childhood encephalopathies and myopathies: a prospective study in a defined population to assess the frequency of mitochondrial disorders. Pediatrics 2000:105:598-603. 